\title{
Pengaruh antara Penerbitan Sukuk Negara terhadap Defisit APBN Indonesia Tahun 2008-2019
}

\section{Bellasuti Solventiani*}

\author{
Prodi Ekonomi Pembangunan, Fakultas Ekonomi dan Bisnis, \\ Universitas Islam Bandung, Indonesia. \\ *bellasutisolventiani@gmail.com
}

\begin{abstract}
The existence of diversification of APBN financing instruments provides an alternative to the Government in financing the budget deficit which tends to increase every year, by establishing policies in accordance with Law Number 19 of 2008 concerning State Sharia Securities, so that the Government begins to use state sukuk as one of the financing instruments. APBN because it is in accordance with the problem to be solved in the form of diversification of APBN financing instruments. The method used in this research is descriptive quantitative approach method. The type of data used in this study is secondary data sourced from the Financial Services Authority (OJK), the Central Statistics Agency (BPS) and the Indonesian Ministry of Finance and other sources. The data used is annual time series data from 2008 to 2019. The analytical method used in this study is the Vector Error Correction Model (VECM). The results show that there is a unidirectional relationship between the budget deficit and Sukuk, in the long term state sukuk have a significant effect on the Indonesian APBN deficit of 0.362388 and vice versa, while in the short-term estimation results, the APBN Deficit variable in lag 3 has a negative and negative effect. significant to the APBN Deficit itself, which is -0.317460 . The APBN deficit response to state sukuk tends to be sensitive, and the contribution made by state sukuk makes a positive contribution to the state budget deficit.
\end{abstract}

Keywords: State Sukuk, Budget Deficit, VECM.

\begin{abstract}
Abstrak. Adanya diversifikasi instrumen pembiayaan APBN memberikan alternatif kepada Pemerintah dalam membiayai defisit anggaran yang mengalami kecenderungan peningkatan setiap tahunnya, dengan menetapkan kebijakan yang sesuai dengan Undang-Undang Nomor 19 Tahun 2008 tentang Surat Berharga Syariah Negara, sehingga Pemerintah mulai menggunakan sukuk negara sebagai salah satu instrumen pembiayaan APBN karena telah sesuai dengan masalah yang ingin dipecahkan berupa adanya diversifikasi instrumen pembiayaan APBN. Metode yang digunakan dalam penelitian yaitu metode pendekatan kuantitatif deskriptif. Jenis data yang digunakan dalam penelitian ini yaitu data sekunder yang bersumber dari Otoritas Jasa Keuangan (OJK), Badan Pusat Statistik (BPS) dan Kementrian Keuangan Indonesia dan sumber-sumber lainnya. Data yang digunakan adalah data runtun waktu (time series) tahunan dari tahun 2008 sampai dengan tahun 2019. Metode analisis yang digunakan dalam penelitian ini yaitu Vector Error Correction Model (VECM). Hasil penelitian menunjukkan bahwa antara defisit anggaran dengan Sukuk memiliki hubungan searah, dalam jangka panjang sukuk negara memiliki pengaruh yang signifikan terhadap defisit APBN Indonesia sebesar 0,362388 dan begitupun sebaliknya, sementara dalam hasil estimasi jangka pendek, variabel Defisit APBN pada lag 3 berpengaruh negatif dan signifikan terhadap Defisit APBN itu sendiri, yaitu sebesar -0.317460. Respon defisit APBN terhadap sukuk negara cenderung sensitif, dan sumbangan yang diberikan sukuk negara memberi kontribusi positif terhadap defisit APBN.
\end{abstract}

Kata Kunci: Sukuk Negara, Defisit APBN, VECM. 


\section{A. Pendahuluan}

Selama ini untuk menutup defisit APBN, Indonesia masih menggunakan utang luar negeri. Tetapi pemerintah tidak bisa terus bergantung pada utang luar negeri karena ia sangat rentan terhadap fluktuasi nilai tukar dan juga suku bunga, di mana ini akan membebankan utang luar negeri dan membebankan APBN yang semakin besar (Amaliah \& Aspiranti, 2017). Pada masa Orde baru ketergantungan Indonesia terhadap modal asing termasuk pinjaman semakin besar, sehingga akhirnya Indonesia dilanda krisis ekonomi yang dikenal dengan sebutan Krisis Keuangan Asia, yang diawali oleh krisis nilai tukar rupiah terhadap dolar AS pada tahun 1997 dan mencapai nilai terendah pada pertengahan tahun 1998. Pada tahun 1997, nilai tukar rupiah terhadap dolar AS adalah Rp.2.000-Rp.3.000. Hingga akhirnya pada bulan Maret 1998, nilai rupiah mencapai Rp.10.550 untuk satu dolar AS (Tambunan, 2018).

Pada tahun anggaran 1998 total realisasi sektor penerimaan APBN RI yang sebesar Rp. 215.130 milyar, 28,97\%-nya dibiayai oleh pinjaman luar negeri. Pinjaman luar negeri yang sedemikian banyak tersebut digunakan untuk menutup defisit anggaran yang besar akibat terjadinya krisis di Indonesia. Krisis ini juga menyebabkan pengeluaran total pemerintah meningkat $68,47 \%$ dari anggaran tahun sebelumnya karena besarnya pos pembayaran cicilan utang luar negeri beserta bunganya yang jatuh tempo menjadi Rp. 55.578 trilyun atau meningkat $88,55 \%$ dari pos yang sama pada anggaran tahun sebelumnya (Atmadja, 2000).

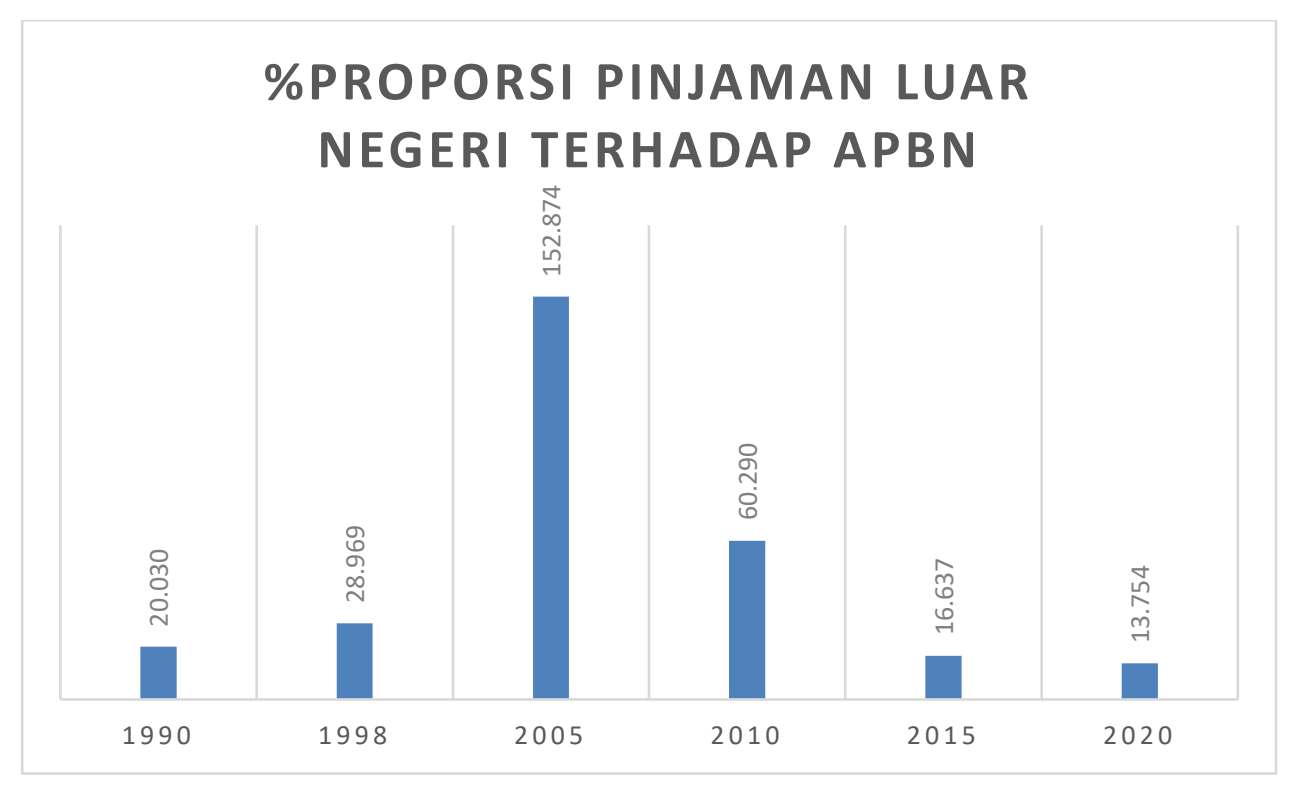

Gambar 1. Proporsi Pinjaman Luar Negeri terhadap APBN (\%)

Sumber: Nota Keuangan, diolah.

Oleh karena utang luar negeri itu risikonya tinggi termasuk terhadap APBN Indonesia, akhirnya membuat Indonesia mencari alternatif lain yang bebas dari bunga maupun fluktuasi nilai tukar salah satunya ialah obligasi syariah atau yang bisa disebut dengan sukuk negara. Sukuk negara merupakan salah satu instrument pembiayaan APBN yang berbentuk Surat Berharga Negara yang penerbitannya didasarkan pada Undang-Undang Nomor 19 Tahun 2008. Sebagai instrument berbasis syariah, penerbitan Sukuk Negara memerlukan underlying asset baik berupa Barang Milik Negara atau proyek APBN (Amaliah et al., 2020). Ini berbeda dengan sukuk korporasi yang penerbitannya dilakukan oleh perusahaan dengan tujuan untuk mendapatkan dana dari masyarakat untuk pengembangan bisnis perusahaan.

Pada tahun 2019 ini terdapat 2 emiten yang pertama kali menerbitkan sukuk korporasi, yaitu PT Mora Telematika Indonesia dan PT Sarana Multigriya Finansial (Persero). Akad yang digunakan dalam penerbitan sukuk korporasi di Indonesia sampai saat ini adalah akad ijarah, 
akad mudharabah, dan akad wakalah. Dari 143 Sukuk korporasi yang outstanding saat ini, terdapat 96 seri sukuk korporasi $(67,13 \%)$ yang menggunakan akad ijarah, 41 seri sukuk korporasi $(28,67 \%)$ menggunakan akad mudharabah, dan 6 seri sukuk korporasi $(4,20 \%)$ menggunakan akad wakalah. Masing-masing akad tersebut mencapai nilai Rp16,62 triliun $(55,71 \%)$ untuk ijarah, Rp1 1,76 triliun $(39,43 \%)$ untuk mudharabah, dan Rp1,45 triliun $(4,86 \%)$ untuk akad wakalah (Otoritas Jasa Keuangan, 2019).

Tabel 1. Total Penerbitan Sukuk Korporasi

\begin{tabular}{|c|c|c|c|c|}
\hline \multirow{2}{*}{ Tahun } & \multicolumn{2}{|c|}{$\begin{array}{c}\text { Total Penerbitan Sukuk } \\
\text { Korporasi }\end{array}$} & \multicolumn{2}{c|}{$\begin{array}{c}\text { Sukuk Korporasi } \\
\text { Outstanding }\end{array}$} \\
\cline { 2 - 5 } & $\begin{array}{c}\text { Total Nilai } \\
\text { (Rp Triliun) }\end{array}$ & Total Jumlah & $\begin{array}{c}\text { Total Nilai } \\
\text { (Rp Triliun) }\end{array}$ & $\begin{array}{c}\text { Total } \\
\text { Jumlah }\end{array}$ \\
\hline 2015 & 16,66 & 87 & 9,9 & 47 \\
\hline 2016 & 20,43 & 102 & 11,88 & 53 \\
\hline 2017 & 26,39 & 137 & 15,74 & 79 \\
\hline 2018 & 36,12 & 175 & 21,3 & 99 \\
\hline 2019 & 48,24 & 232 & 29,83 & 143 \\
\hline
\end{tabular}

Sumber: OJK, 2019.

Saat ini sukuk telah menjadi salah satu instrumen pembiayaan resmi yang memiliki peran penting dalam mendukung pertumbuhan sektor riil Indonesia (Amaliah \& Aspiranti, 2017). Implementasi kebijakan penerbitan Sukuk Negara sebagai instrument pembiayaan defisit APBN terjadi untuk pertama kalinya pada tanggal 26 Agustus 2008 dengan diterbitkannya Sukuk Negara seri Ijarah Fixed Rate (IFR) 001 senilai Rp. 2,71 T dan seri IFR 002 senilai Rp. 1,98 T. Penerbitan Sukuk Negara terus mengalami peningkatan dari tahun ke tahunnya, sesuai dengan perkembangan dan strategi yang di terapkan dalam APBN. Dapat dilihat pada tabel 2 penerbitan pada tahun 2013 sebesar Rp. 53,2 triliun menjadi sebesar Rp. 213,9 triliun pada tahun 2018. Tugas dalam memenuhi pembiayaan defisit APBN yang terus meningkat, maka pemerintah terus melakukan pengembangan instrument SBSN atau Sukuk Negara (Hariyanto, 2017b).

Tabel 2. Perkembangan Penerbitan SBSN tahun 2013-2018

\begin{tabular}{|c|c|c|c|c|c|c|}
\hline \multirow{2}{*}{$\begin{array}{c}\text { Instrume } \\
\mathrm{n}\end{array}$} & \multicolumn{5}{|c|}{ Tahun (juta rupiah) } \\
\cline { 2 - 7 } & 2013 & 2014 & 2015 & 2016 & 2017 & 2018 \\
\hline PBS & $9,316,000$ & $9,446,000$ & $46,248,000$ & $91,886,000$ & & $\begin{array}{c}104,513,71 \\
4\end{array}$ \\
\hline USDPBS & & & & & & $1,576,400$ \\
\hline PBSNT & & & & & & $1,500,000$ \\
\hline SPN-5 & $\begin{array}{c}11,653,00 \\
0\end{array}$ & $161,170,00$ & $14,295,000$ & $16,986,000$ & $44,690,000$ & $51,680,000$ \\
\hline SR & $\begin{array}{c}14,969,00 \\
0\end{array}$ & $19,323,000$ & $21,965,035$ & $31,500,000$ & $14,037,310$ & $8,436,570$ \\
\hline SDHI & & $12,855,000$ & $4,500,000$ & $1,000,000$ & $2,000,000$ & \\
\hline SNI & $\begin{array}{c}17,238,00 \\
0\end{array}$ & $17,747,000$ & $26,422,000$ & $33,407,500$ & $39,969,000$ & $41,379,000$ \\
& & & & & \\
\hline
\end{tabular}




\begin{tabular}{|c|c|c|c|c|c|c|}
\hline $\begin{array}{c}\text { SPN- } \\
5 N T\end{array}$ & & & $5,084,143$ & $2,535,030$ & & \\
\hline ST & & & & $2,585,122$ & & $4,945,682$ \\
\hline & $\begin{array}{c}53,176,00 \\
0\end{array}$ & $75,541,000$ & $\begin{array}{c}118,514,17 \\
8\end{array}$ & $\begin{array}{c}179,898,65 \\
2\end{array}$ & $\begin{array}{c}192,494,26 \\
7\end{array}$ & $\begin{array}{c}213,931,36 \\
6\end{array}$ \\
\hline
\end{tabular}

Sumber: Sukuk: Suatu Telaah dari Variabel Makro Ekonomi/Ima Amaliah,dkk.

Berdasarkan latar belakang yang telah diuraikan, maka perumusan masalah dalam penelitian ini sebagai berikut: "Apakah terdapat hubungan kausalitas antara sukuk negara dengan defisit APBN di Indonesia pada tahun 2008-2019?, Bagaimanakah pengaruh defisit APBN terhadap penerbitan sukuk negara di Indonesia tahun 2008-2019 baik dalam jangka pendek maupun jangka panjang?, Bagaimana pengaruh sukuk negara terhadap guncangan defisit APBN?". Selanjutnya, tujuan dalam penelitian ini diuraikan dalam pokok-pokok sbb.

1. Untuk mengetahui hubungan kausalitas antara sukuk negara dan defisit APBN di Indonesia tahun 2008-2019, satu arah atau dua arah.

2. Untuk mengetahui besarnya pengaruh dari defisit APBN terhadap penerbitan sukuk di Indonesia tahun 2008-2019 dalam jangka pendek dan jangka panjang.

3. Untuk mengetahui besarnya pengaruh defisit APBN terhadap guncangan sukuk negara.

\section{B. Metodologi Penelitian}

Peneliti menggunakan metode penelitian kuantitatif deskriptif, yaitu menganalisis data dengan cara mendeskripsikan atau menggambarkan data yang telah terkumpul sebagaimana adanya. Jenis penelitian yang dilakukan adalah survey literature yang merupakan tinjauan dari sumbersumber data yang dikumpulkan. Data yang digunakan adalah data runtun waktu (time series) tahunan dari tahun 2008 sampai dengan tahun 2019 yang diperoleh dari Otoritas Jasa Keuangan (OJK), Badan Pusat Statistik (BPS) dan Kementrian Keuangan Indonesia dan sumber-sumber lainnya.

Metode analisis yang akan digunakan dalam penelitian ini yaitu Vector Error Correction Model (VECM), analisis VECM ini bertujuan untuk melihat pengaruh variabel independen terhadap variabel dependen dalam jangka pendek maupun jangka panjang.

\section{Hasil Penelitian dan Pembahasan}

\section{Analisis Kausalitas Grangger/Granger Causality Test}

Dalam hasil uji kausalitas dapat dijelaskan bahwa yang memiliki hubungan kausalitas adalah variabel dengan nilai probabilitas (p value) lebih kecil dari $\alpha 0,05(\alpha<5 \%)$. Tabel 3 di bawah ini menunjukkan hasil uji kausalitas antara Sukuk Negara dengan Defisit APBN. Berikut hasil uji kausalitasnya :

Tabel 3. Hasil Uji Kausalitas

\begin{tabular}{lccc}
\hline \hline Null Hypothesis: & Obs & F-Statistic & Prob. \\
& & & \\
\hline \hline & 45 & 0.01664 & 0.9970 \\
DAPBN does not Granger Cause SUKUK & 45.06 & 13.3377 & $4 . E-06$
\end{tabular}

Sumber: Eviews 9, data diolah.

Dari hasil uji kausalitas pada tabel di atas variabel sukuk memiliki hubungan kausalitas searah terhadap defisit APBN karena probabilitasnya sebesar 4,E-06 yang berarti lebih kecil dari 0,05. Hasil penelitian tersebut menunjukan bahwa antara defisit anggaran dengan Sukuk memiliki hubungan searah dimana semakin tinggi defisit anggaran maka semakin banyak sukuk 
yang diterbitkan.

\section{Analisis Pengaruh Defisit APBN terhadap Penerbitan Sukuk Negara dalam Jangka Pendek dan Jangka Panjang}

VECM yaitu model ekonometrika yang digunakan untuk mengetahui tingkah laku jangka pendek dari suatu variabel terhadap jangka panjangnya (Ajijja et al., 2011). Cara membaca estimasi VECM dengan membandingkan nilai t-statistik dengan t-tabel. Apabila t-statistik lebih besar dari t-tabel maka variabel independen secara signifikan berpengaruh terhadap variabel dependen, dapat disimpulkan H0 ditolak. Berikut hasil estimasi VECM jangka pendek pada tabel 4.

Tabel 4. Estimasi VECM Jangka Pendek

\begin{tabular}{|c|c|c|c|c|c|c|}
\hline \multirow{2}{*}{$\begin{array}{c}\text { Error } \\
\text { Correction: }\end{array}$} & \multicolumn{3}{|c|}{ D(DAPBN) } & \multicolumn{3}{c|}{ D(SUKUK) } \\
\cline { 2 - 7 } & koefisien & $\begin{array}{c}\text { Standar } \\
\text { error }\end{array}$ & Thitung/Tstat & koefisien & $\begin{array}{c}\text { Standar } \\
\text { error }\end{array}$ & Thitung/Tstat \\
\hline CointEq1 & - & $(0.44214)$ & {$[-2.99329]$} & 0.225453 & $(0.14085)$ & {$[1.60064]$} \\
\hline $\mathrm{D}($ DAPBN(-1)) & 0.1823 .454 & & & -0.194934 & $(0.11233)$ & {$[-1.73538]$} \\
\hline $\mathrm{D}($ DAPBN(-2)) & -0.197595 & $(0.26167)$ & {$[-0.75512]$} & -0.138409 & $(0.08336)$ & {$[-1.66036]$} \\
\hline $\mathrm{D}($ DAPBN(-3)) & -0.317460 & $(0.16187)$ & {$[-1.96124]$} & -0.086033 & $(0.05157)$ & {$[-1.66842]$} \\
\hline $\mathrm{D}($ SUKUK(-1)) & 0.364736 & $(0.56425)$ & {$[0.64641]$} & -0.187307 & $(0.17975)$ & {$[-1.04203]$} \\
\hline $\mathrm{D}($ SUKUK(-2)) & 0.855309 & $(0.54564)$ & {$[1.56753]$} & 0.124130 & $(0.17382)$ & {$[0.71411]$} \\
\hline $\mathrm{D}($ SUKUK(-3)) & -0.159708 & $(0.57098)$ & {$[-0.27971]$} & 0.034416 & $(0.18190)$ & {$[0.18921]$} \\
\hline
\end{tabular}

Sumber: Eviews 9, data diolah.

Dalam penelitian ini degree of freedom berjumlah 44. Analisis VECM memperhatikan perbandingan nilai $t$ statistic dengan $t$ tabel, maka dari nilai degree of freedom 44 di dapatkan nilai t tabel adalah 1,680 dengan nilai rentang $\mathrm{p}$ value 0,025 dan $-0,025$ (nilai kritis sebesar 5\%).

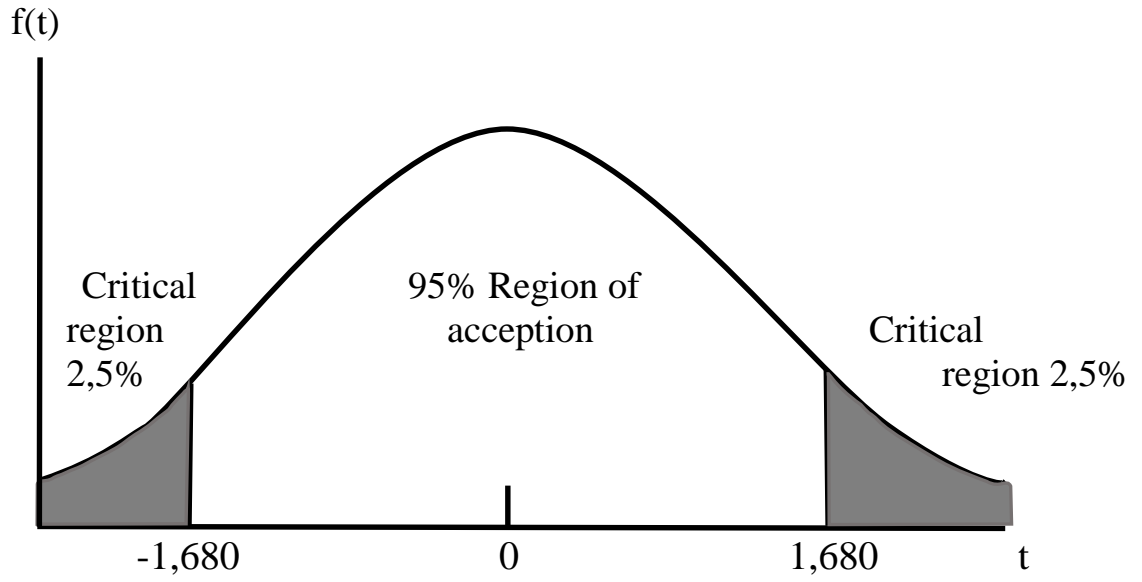

Gambar 2. Kurva Uji t

Hasil estimasi dalam jangka pendek menunjukan bahwa variabel defisit APBN pada lag satu berpengaruh negatif dan signifikan terhadap variabel sukuk sebesar -0.194934. Artinya, apabila terjadi kenaikan Defisit APBN sebesar satu satuan (satu milyar rupiah) pada kuartal sebelumnya, maka akan menurunkan Sukuk Negara pada kuartal sekarang sebesar 0.194934. Pada lag ketiga berpengaruh negatif dan signifikan terhadap defisit APBN itu sendiri sebesar 0.317460. Artinya, apabila terjadi kenaikan Defisit APBN sebesar satu satuan (satu milyar rupiah) pada 3 kuartal sebelumnya, maka akan menurunkan Defisit APBN pada kuartal sekarang sebesar 0.317460 . 
Tabel 5. Estimasi VECM Jangka Panjang

Standard errors in ( ) \& t-statistics in [ ]

\begin{tabular}{cc}
\hline \hline Cointegrating Eq: & CointEq1 \\
\hline \hline DAPBN(-1) & 1.000000 \\
SUKUK(-1) & 0.362388 \\
& $(0.03978)$ \\
& {$[9.10932]$} \\
C & -5264.545
\end{tabular}

Sumber: Eviews 9, data diolah.

Berdasarkan tabel 5 terlihat bahwa hasil estimasi VECM jangka panjang pada variabel Sukuk Negara memiliki t-statistik yang lebih besar dari t tabel dimana 9,10932 > 1,680 dengan koefisien 0,362388. Hal ini menunjukan H0 ditolak, sehingga Sukuk Negara memiliki pengaruh yang signifikan terhadap Defisit APBN Indonesia. Dengan demikian setiap kenaikan Sukuk Negara sebesar satu satuan (satu milyar rupiah) berpengaruh terhadap kenaikan Defisit APBN sebesar 0,362388 dan begitupun sebaliknya.

\section{Analisis Pengaruh dari Shock/Guncangan Defisit APBN terhadap Penerbitan Sukuk Negara serta Kontribusinya.}

Pada analisis ini IRF (Impulse Respon Function) menggambarkan bagaimana perkiraan dampak dari shock suatu variabel terhadap variabel-variabel penelitian lain sehingga bisa diketahui berapa lama pengaruh shock atau goncangan suatu variabel terhadap variabel lain yang dirasakan dan variabel manakah yang akan memberi response terbesar terhadap shock (Batubara \& Saskara, 2015). Hasil IRF dapat dilihat pada Tabel 6.

Tabel 6. Nilai Impulse Respon Function Variabel Defisit APBN dan Sukuk Negara

\begin{tabular}{|c|c|}
\hline \multicolumn{2}{|c|}{ Response of $\mathrm{D}(\mathrm{DAPBN})$ : } \\
\hline Period & $\mathrm{D}(\mathrm{SUKUK}) \mathrm{D}(\mathrm{DAPBN})$ \\
\hline 1 & $-5706.064 \quad 66412.78$ \\
\hline 2 & $-3581.637-54068.18$ \\
\hline 3 & $9322.915-16219.69$ \\
\hline 4 & $-16887.14 \quad 18793.36$ \\
\hline 5 & $13128.66 \quad 31535.12$ \\
\hline 6 & $-8345.347-31151.93$ \\
\hline 7 & $6022.996-15256.05$ \\
\hline 8 & $-14791.30 \quad 18895.76$ \\
\hline 9 & $15112.88 \quad 18302.63$ \\
\hline 10 & $-8128.133-22106.95$ \\
\hline
\end{tabular}

Sumber: Eviews 9, data diolah.

Berdasarkan hasil IRF menunjukan hasil sebagai berikut. Pada periode pertama, ketika terjadi shock/guncangan pada Sukuk Negara sebesar 1 milyar maka Defisit APBN akan memberikan respon negatif sebesar -5706.064. Secara keseluruhan respon Defisit APBN terhadap Sukuk cenderung sensitive. 

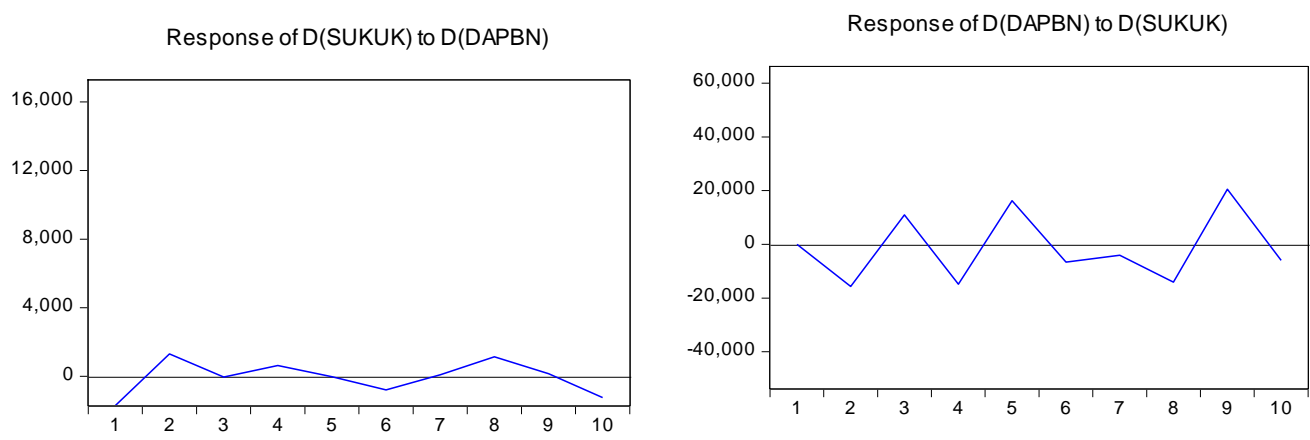

Gambar 3. Impulse Response Variabel Sukuk Negara dan Defisit APBN

Sumber: Eviews 9, data diolah.

Setelah analisis terhadap perilaku dinamis model melalui impulse respon function, maka selanjutnya akan dilihat karakteristik model melalui Variance Decomposition. Analisis Variance Decomposition (VD) bermanfaat untuk menjelaskan kontribusi dari masing-masing vairabel terhadap guncangan yang ditimbulkannya terhadap variabel endogen utama yang diamati. Analisis ini digunakan untuk memprediksi seberapa besar kontribusi varians setiap variabel berpengaruh terhadap variabel lainnya pada saat ini dan periode kedepannya. Hasil variance decomposition dapat dilihat pada tabel 7.

Tabel 7. Hasil Uji Variance Decomposition

\begin{tabular}{cccc}
\hline \hline $\begin{array}{c}\text { Variance } \\
\text { Decomposition of } \\
\text { D(DAPBN): } \\
\text { Period }\end{array}$ & S.E. & D(SUKUK) & D(DAPBN) \\
\hline \hline & 16557.99 & 0.732784 & 99.26722 \\
1 & 16723.97 & 0.615053 & 99.38495 \\
2 & 16851.57 & 1.711697 & 98.28830 \\
3 & 16934.33 & 4.989135 & 95.01086 \\
4 & 19202.88 & 6.186325 & 93.81368 \\
5 & 19301.52 & 6.236460 & 93.76354 \\
6 & 19469.92 & 6.416278 & 93.58372 \\
7 & 19548.12 & 8.008598 & 91.99140 \\
8 & 20257.23 & 9.538107 & 90.46189 \\
9 & 20343.87 & 9.642996 & 90.35700 \\
10 & & & \\
\hline \hline
\end{tabular}

Sumber: Eviews 9, data diolah.

Tabel 7 menunjukan hasil dimana sumbangan yang diberikan oleh Sukuk Negara bersifat kuat dengan besaran pada periode pertama yaitu $0.73 \%$. Walaupun pada periode ke dua sempat mengalami penurunan tetapi pada periode 3 hingga periode 10 terus mengalami kenaikan maka dari itu sumbangan yang diberikan Sukuk Negara terus menguat.

\section{Kesimpulan}

Berdasarkan pembahasan dalam penelitian ini, peneliti menyimpulkan beberapa hasil penelitian sebagai berikut:

1. Hasil uji kausalitas menunjukan bahwa adanya hubungan kausalitas satu arah antara sukuk negara terhadap defisit APBN karena nilai probabilitas yang kurang dari 0,05. Artinya saat terjadinya perubahan pada sukuk negara, maka akan mengakibatkan terjadinya perubahan pada defisit APBN, sehingga secara kausalitas sukuk negara efektif dalam mengatasi defisit APBN.

2. Dalam hasil estimasi jangka pendek, variabel Defisit APBN pada lag 3 berpengaruh 
negatif dan signifikan terhadap Defisit APBN itu sendiri, yaitu sebesar -0.317460 . Artinya, Defisit APBN pada saat mengalami kenaikan sebesar satu satuan (satu milyar rupiah) pada 3 kuartal sebelumnya, maka akan menurunkan Defisit APBN pada kuartal sekarang sebesar 0.317460. Sementara, hasil estimasi VECM dalam jangka panjang menunjukan bahwa sukuk negara memiliki pengaruh yang signifikan terhadap defisit APBN Indonesia.

3. Secara keseluruhan respon defisit anggaran terhadap sukuk cenderung sensitive, dimana pada periode pertama ketika terjadinya shock pada sukuk negara direspon negative oleh defisit APBN, begitu pula pada periode kedua dan ke-empat. Hasil variance decomposition menunjukan hasil dimana sumbangan yang diberikan oleh Sukuk Negara memberikan kontribusi positif permanen dan bersifat kuat dengan besaran pada periode pertama yaitu $0.73 \%$.

\section{Acknowledge}

Peneliti mengucapkan terima kasih banyak kepada seluruh pihak yang telah membantu dalam menyelesaikan penelitian ini. Khususnya kepada kedua pembimbing peneliti yaitu ibu Dr. Ima Amaliah, SE., M.Si, selaku pembimbing pertama dan kepada bapak Meidy Haviz, SE., M.Si, selaku pembimbing kedua peneliti.

\section{Daftar Pustaka}

[1] Ajijja, S. R., Sari, D. W., Setianto, R. H., \& Primanti, M. R. (2011). Cara Cerdas Menguasai EViews. Salemba Empat.

[2] Amaliah, I., \& Aspiranti, T. (2017). State sukuk potential in reducing Indonesia budget deficit , 2009 -. 20(1), 21-30.

[3] Amaliah, I., Aspiranti, T., Riani, W., Putri, C. U. C., \& Pratiwi, P. W. (2020). Sukuk Suatu Telaah dari Variabel Makro Ekonomi. PT RajaGrafindo Persada.

[4] Atmadja, A. S. (2000). Utang Luar Negeri Pemerintah Indonesia : Puslit.Petra.Ac.Id, 2(1), 83-94.

[5] Batubara, D. M. H., \& Saskara, I. A. N. (2015). Analisis Hubungan Ekspor , Impor, PDB , Causality And Co-Integration Analysis Between Exports , Imports ,. Jurnal Ekonomi Kuantitatif Terapan, 8(1), 46-55.

[6] Hariyanto, E. (2017b). Peran Strategis Sukuk Negara. Direktorat Pembiayaan Syariah, DJPPR, Kementerian Keuangan, 1-3.

[7] Otoritas Jasa Keuangan. (2019). Laporan Perkembangan Keuangan Syariah Indonesia 2019 Sinergi Dalam Membangun Ekosistem Ekonomi dan Keuangan Syariah. Otoritas Jasa Keuangan, 53(9), 18.

[8] Tambunan, T. T. H. (2018). Perekonomian Indonesia 1956-2018. Ghalia Indonesia. 